\title{
INFLUENCE OF PERCEIVED USEFULNESS AND EASE OF USE ON STUDENTS' CONTINUOUS INTENTION IN LEARNING ON-LINE ENGLISH LESSONS: AN EXTENDED TAM
}

\author{
Akmal \\ University of Ahmad Dahlan, Indonesia \\ akmal@mpbi.uad.ac.id
}

\begin{abstract}
There are huge numbers of English lessons available on-line and are ready to be used by TEFL and ELT teachers for teaching Listening, Speaking, Reading, Writing, Pronunciation, Grammar, etc. Some on-line English lessons may receive less attention from the students as the web pages are too complicated or the addresses are too difficult to be accessed. It can be caused by improper choice of learning template such as Moodle, Edmodo, the Blackboard system, etc or caused by type of application used such as Wondershare, PPT Macros, Aurora 3D, Zondle, Hotpotato, iMindmap, Drop Box, Edmodo, ToolBook, Smashwords, Amazon Kindle DX, PowToon, and so forth. Therefore, it is critical to understand students' continuous intention in following on-line English lessons. This study was aimed at assessing the influence of Perceived Usefulness and Ease of Use on Students' Continuous Intention in learning on-line English Lessons. There were 230 pre-service English students (4A-4E classes) who took compulsory course of Teaching Media/ Instructional Technology during the academic year of 2016/2017. The students were divided into several groups for joining on-line English lessons of Listening, Speaking, Reading, Writing, Pronunciation, Grammar, Vocabulary, and TOEFL. While joining those on-line lessons, the researcher measured their continuous attention from ease-of-use, and perceived usefulness of extended Technology Acceptance Model (TAM). The data were collected through questioners and analysed by using Structural Equation Modelling (SEM).The results indicate that the students' intentions are influenced positively by the design of the lessons, lessons delivery/ease-of-use, and their perceived usefulness. Perceived usefulness (PU) influenced more on students' motivation than ease-of-use (PEOU). It is recommended that designers of on-line English lessons should consider students' prior knowledge of ICT, pedagogical principles, and technological barrier in the students' location for receiving more positive enduring intention.
\end{abstract}

Keywords: extended TAM, perceived usefulness, ease of use, continuous intention online English lessons

\section{INTRODUCTION}

There are huge numbers of English lessons available on-line and are ready to be used by TEFL and ELT teachers for teaching Listening, Speaking, Reading, Writing, Pronunciation, Grammar, etc. Some on-line English lessons have received a little attention from the students as the web pages are too complicated or the addresses are too difficult to be accessed. It can be caused by improper choice of learning template such as Moodle, Edmodo, the Blackboard system, etc or caused by type of application used such as Wondershare, PPT Macros, Aurora 3D, Zondle, Hotpotato, iMindmap, Drop Box, Edmodo, ToolBook, Smashwords, Amazon Kindle DX, PowToon, and so forth. In order to proactively achieve the learning goals and design interventions (teacher training, user orientation, students assessment and evaluation), it is essential for online learning designers to understand how to make use of multimedia components, attract the attention of the users, and more inclined to adopt and use online learning systems. 
Since the students are the end-users of online learning system, the lesson designers need an attractive channel to deliver the content of the lessons. The attention of the students on the lessons, for example, can be kept by providing menu and tools for communication channel, discussion forum, message boards, and chat rooms. In order to make it effective and useful for the learners, the contents of the lesson should be interpreted by multimedia specialist in an attractive, economical, and communicative way. In doing so, multimedia does not only function as a means of communication but also increases students' learning motivation, attention and lead to the success of the students. Commonly Technology Acceptance Model (TAM) is used to measure employees' working performance upon the use of new technology. The researcher, however, is very interested to use TAM for predicting the students' continuous attention in joining on-line English lessons since TAM deals with variables affecting perceived usefulness (PU) and Perceive ease of use (PEOU). Perceived ease of use and usefulness affect attitudes toward usability that shapes intention to use online English lessons.

\section{LITERATURE REVIEW}

The degree to which a person believes that using a particular system would enhance his or her job performance is called perceives usefulness/PU (Davis 1989, p. 320) while perceived ease of use (PEOU) refers to the degree to which a person believes that using a particular system would be free of effort. PU is the notion of a person that technology has benefits. For instance, it can enhance his/her proficiency while PEOU is a person's notion of how easy it is to use technology.

In conjunction with TAM effectiveness, an empirical study was carried out by Fang \& Zhao (2010) to investigate the relationship between media enjoyment theories, personality theories, effects of computer game play, and technology acceptance model (TAM).Their findings suggest that an appropriate fit between characteristics of the player and gaming technology result in greater enjoyment while social influence may moderate effects of the fit. Another research done by Chung et al (2010) on game players found they cannot comprehensively predict the attitude and behaviour of online games players because there are social influences and gender effect on college students' attitude in playing online game. Their results are true since perceived usefulness in the TAM model originally referred to job related productivity, performance, and effectiveness (Davis,1989). It is not related to game players who seek for entertainment. Other empirical studies have also confirmed that there are some other key factors in TAM model such as consumer's age, gender, and experience (Venkatesh \& Davis, 2000; Venkatesh et al., 2003). TAM first model then was improved by Venkatesh and Davis (2003) into Extended TAM which covers social influence (subjective norms, voluntariness, image) and cognitive instrumental processes (job relevance, output quality, result demonstrability, perceived ease of use) as an additional predictor of intention in the case of mandatory settings.

Learning performance was found to have positive relationships with perceived usefulness of on-line technology. This idea was supported by Lee \& Lee (2008) which found that perceived usefulness was defined as the user's belief that the technology will improve their learning performance. This showed that the more students perceived useful, the higher their learning performance was. Moreover, the more students demonstrated their acceptance of on-line learning to be used for studying English, the higher their language ability was. 
It is also found that perceived usefulness and perceived ease of use positively affect consumers' intention in using the Internet. It is meant that an intuitive user interface can make their work easier and hence perform the job more efficiently. Many researches have demonstrated that perceived ease of use will likely enhance perceived usefulness (Taylor \& Todd, 1995; Venkatesh \& Davis, 2000). Such relationship has further been supported by the extended TAM (Agarwal \& Prasad, 1999; Davis, 1989; Van der Heijden, 2004; Venkatesh \& Davis, 2000; Venkatesh \& Morris, 2003; Wixom \& Todd, 2005).

\section{METHODS}

There were 300 pre-service English students (4A-4F classes) who took compulsory course of Teaching Media / Instructional Technology during the academic year of 2016/2017 taken as the sample of the population. They were asked to join on-line English lessons for three months. As integrated part of the syllabus, the students were demanded to join on-line English lessons for three months prior to class room activities. At the end of the course, they should answer the questioner about the on-line English lessons. TAM questionnaires were divided into two parts--personal information of the users; age, education, occupation, experiences of using multimedia online learning and frequency of usage, and theoretical constructs of the proposed model to measure users' perception regarding the continued use of multimedia online learning. The questionnaires were distributed to 300 respondents but only 283 were returned duly filled responses. Answers to the statement were coded between 1 up to 5 of Linker scales. Data were analysed by using SEM software using Confirmatory Factor Analyses (CFA) in which manifest variables under each latent variable was investigated for fit. Direct and indirect effects of latent variables towards other latent variables were observed. Validity of the model is based on goodness of fit statistics. The measure to validate the model for goodness of fit statistics are Chi Square ( $p$ value), Root Mean Square Error Approximation (RMSEA), Normed Fit Index (NFI), Goodness of Fit Index (GFI), and Adjusted Goodness of Fit Index (AGFI). The researcher has the hypotheses that (1).Perceived ease of use has positive effect on continuous intention, (2).Perceived usefulness has a positive effect on continuous intention, and (3).Perceived ease of use has a positive effect on Perceive usefulness.

The conceptual framework in this study is given below:

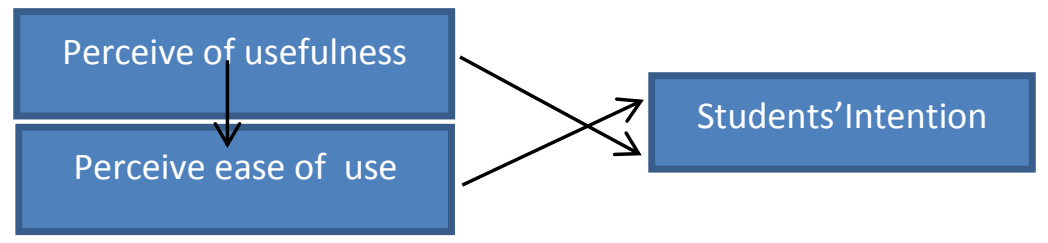

Research Questions are;

1. What are the students' perceived ease of use and usefulness of on-line English lessons?

2. Are there any relationships among the students' intention, perceived ease of use, perceived usefulness of on-line English lessons?

\section{FINDINGS AND DISCUSSION}

Table 1 below shows that the value of Chi-Square(p-value) 0.148 which is greater than 0.10.Since Chi-Square is a statistics fit which specifies whether model provides is a perfect fit to data (within the limits of sampling error) or not. When pvalue is greater than 0.01 , it indicates good fit and when it is closer to 1 , it indicates 
perfect fit. It can be inferred that the model of the research is a very good fit to the data. Then its Root Mean Square Error Approximation (RMSEA) is close fit. The value 0.05 or below is very close fit, 0.08 and below is still acceptable, but never use 0.1 and above.

Table 1. Goodness of Fit Statistics /SEM Results.

\begin{tabular}{|l|l|l|}
\hline \multicolumn{1}{|c|}{ Index } & \multicolumn{1}{|c|}{ Acceptance value } & \multicolumn{1}{c|}{ Value } \\
\hline Chi-Square (P-value) & $>0.01$ & 166.78 \\
Root Mean Square Error (RMSEA) & $<0.08$ & $(0.14858)$ \\
Normed Fit Index (NFI) & Close to 0.9 is a very & 0.051 \\
Non-Normed Fit Index (NNFI) & good fit Close to 0.9 is & 0.912 \\
Goodness of Fit Index (GFI) & a very good fit Close to & 0.979 \\
Adjusted Goodness of Fit Index & 0.9 is a very good fit & 0.947 \\
(AGFI) & Close to 0.9 is a very & 0.917 \\
& good fit & \\
\hline
\end{tabular}

Its Norm Fit Index (NFI) is closed to 0.9 indicating a good model fit. NFI value for this model is 0.852 which is greater than 0.9 . It means that the model is a very good fit to the data. Non-Normed Fit Index (NNFI) is modified version of NFI designed to lessen its dependence on sample size. NNFI for this study is 0.979 which signifies a very good fit. Goodness of fit Index (GFI) is proportion of the variances and co-variances. This index should fall between 0 and 1 though it can be smaller than 0 . The values which are greater than 0.9 sometimes are fine. GFI for this study is 0.947 , meaning a very good fit of the model. The AGFI for this study is 0.917 which means a very good fit for the data. Based on those findings, it can be said that the model shows a very good fit to the data.

It can be interpreted from the data that (1) students' perceived ease of use (PBEU) significantly influence continuance intention toward multimedia online learning. It is in accordance with Venkatesh (2003) finding that perceived ease of use is an important factor in the early stages of a system's use. The importance of ease of use can affect the student understanding the contents of the web. Consequently, students will increase their motivation to study actively; (2) students' perceived usefulness directly affects student consistent intention. This is in line with findings mentioned by Wixom \& Todd (2005) that perceived usefulness is more important than perceived ease of use in predicting the acceptance of new technologies but in contrast with Park, (2009); Chang et al., (2012); Adwan et al.,(2013); Shroff et al,(2011) findings that perceived ease of use had the strongest significant influence on perceived usefulness.

In order to enhance the usefulness of the multimedia online learning, it will be important that the designers of online learning should have an accurate grasp of user needs and design the multimedia English lessons.

This research also confirmed that (3) students' perceived ease of use positively effects on students' perceived usefulness, consistent with the findings of most studies of the extended TAM model. Students' ease of use has a direct effect on student continuance intention of multimedia English lessons. This finding is consistent with previous study of hedonic information systems (Van der Heijden, 2004). Thus, online learning designers are advised to design multimedia interface, contents and interaction which are very easy to use and follow, especially for the new students. 


\section{CONCLUSION}

There are many English lessons available on-line and they are ready to be used by TEFL and ELT teachers as the sources of teaching supplement materials. They may use on-line English lessons for teaching Listening, Speaking, Reading, Writing, Pronunciation, Grammar, etc. Some on-line English lessons have received a little attention from the students as the web pages are too complicated or the address is too difficult to access. Therefore, it is critical to understand factors that determine student continuous intention in following on-line English lessons. This study has found that positive students' perceived usefulness and perceive ease of use have a positive effect on continuous intention. The greater of those indicators correspond with the higher continuous intention. This research found positive effect of student perceived usefulness, and student perceived ease of use on continuous intention. Significant results of student perceived usefulness and student flow experience were obtained in most relationships as expected. Since the students' IT background are not homogenous, various internet speed, different language skills, and inconsistent lessons format, there may some bias of the answers given by the students.

\section{REFERENCES}

Adwan, A., \& Smedley, J. (2013). Exploring students' acceptance of elearning using technology acceptance model in Jordanian Universities. International Journal of Education and Development using Information and Communication Technology, 9(2), 4-18.

Agarwal, R. and Prasad, J. (1999) Are Individual Differences Germane to the Acceptance of New Information Technologies? Decision Sciences, 30, 361-391.

Chang, C., Yan, C., \& Tseng, J. (2012). Perceived convenience in an extended technology acceptance model: Mobile technology and English learning for college students. Australasian Journal of Educational Technology, 28 (5), 809-826.

Davis, F. D. (1989). Perceived usefulness, perceived ease of use \& user acceptance of information technology. MIS Quarterly,13, 319-340.

Fang, X., Zhao, F.(2010). Personality and enjoyment of computer game play, Computers in Industry 61, 342-349.

Lee, J.-K., \& Lee, W.-K. (2008). The relationship of e-learner's self-regulatory efficacy and perception of e-learning environmental quality. Computers in Human Behavior, 24(1), 32-47

Park, S. (2009). An analysis of the technology acceptance model in understanding university students' behavioural intention to use eLearning. Education Technology \& Society, 12(3), 150-162.

Shroff, R. H., Deneen, C. D. \& Ng, E. M. W. (2011). Analysis of the technology acceptance model in examining students' behavioural intention to use an e-portfolio system. Australasian Journal of Educational Technology, 27(4), 600- 618.

Taylor,S \& Peter.A.Todd.(1995).Understanding Information Technology Usage: A Test of Competing Models. Information Systems Research. 6 (2), 144-176.

Van der Heijden, H. (2004). User acceptance of hedonic information systems. MIS Quarterly, 28(4), 695-704. 
Venkatesh,V and Fred D. Davis (2000).A Theoretical Extension of the Technology Acceptance Model: Four Longitudinal Field Studies. Management Science. Vol. 46, No. 2 (Feb., 2000), pp. 186-204

Venkatesh, V., Michael G. Morris, Gordon B. Davis, Fred D. Davis.(2003).

User Acceptance of Information Technology: Toward a Unified View. MIS Quarterly, Vol. 27, No. 3. pp. 425-478 